\title{
Cost-effectiveness of groundwater conservation measures: A multi-level analysis with policy implications
}

\author{
Irene Blanco-Gutiérrez ,Consuelo Varela-Ortega , Guillermo Flichman \\ Department of Agricuitural Economics and Soctal Sciences, Universidad Politécnica de Madrid, Av. Complatense s/n, 28040 Madrid, Spain \\ Mediterranean Agtonomic institute of Montpelier, CIHEAM, 3191 Route de Mende, 34093 Montpellier Cedex 5, France
}

Keywords:

Groundwater resoutces

Irrigation

Wetlands conservation

Multi-scale economic modeling

Water policies

Cost-effectiveness analysis

\begin{abstract}
A B S T R A C T
Groundwater in Spain, as in other arid and semiarid countries worldwide, has been widely used in the expansion of irrigated agriculture. In the Spanish Mancha Occidental aquifer, the excessive, and sometimes illegal, water abstraction for irrigation has promoted outstanding socioeconomic development in the area, but it has also resulted in exploitation of the aquifer and degradation of valuable wetlands. Water policies implemented in the region have not yet managed to restore the aquifer and face strong social opposition. This paper uses a multi-scale modeling approach to explore the environmental and socio-economic impacts of alternative water conservation measures at the farm and basin levels. It also analyzes their comparative cost-effectiveness to help policy makers identify the least costly policy option for achieving the goal of the Mancha Occidental aquifer's sustainability. To conduct this analysis, a Mathematical Programming Model has been developed to simulate: the closing-up and taxed-legalization of unlicensed wells, uniform volumetric and block-rate water prices, water quotas, and water markets. Aggregate results show that net social costs are not substantially different across policy option, so none of the considered policy options will be clearly more cost-effective than the others. However, there are significant differences between private and public costs (at the fam and sub-basin levels), which will be critical for determining the application in practice of these policies. Results show that controlling illegal water mining (through the legalization of unlicensed wells) is necessary, but is not sufficient to recover the aquifer. Rather, effective water management in this area will require the implementation of other water management policies as well. Among them, uniform volumetric and block-rate water pricing policies will entail the lowest net social cost, but will produce important income losses in the smallest and most water-intensive farms, which might put at risk the viability of these farms and the social acceptance of the policies. Further investigations on social costs, policy enforcement capacity and public participation in water management are highly recommended.
\end{abstract}

\section{The problem: groundwater development and wetlands preservation}

Groundwater in Spain, as in other arid or semiarid countries worldwide, has been widely used in the expansion of irrigated agriculture (Giordano and Villholth, 2007; Llamas and MartínezSantos, 2005; Shab et al., 2007). This phenomenon has helped to stimulate the socioeconomic development in rural communities (Foster and Chilton, 2003; Varela-Ortega, 2007). However, in many cases, the largely uncontrolled agricultural groundwater use has produced far-reaching environmental and social problems (water table depletion, groundwater quality degradation, destruction of associated water ecosystem, proliferation of free-riding behaviors) (Schuyt, 2005). This is a clear fact in several Spanish aquifers, in which groundwater is the primary water source for all uses (Garrido et al., 2006), but it is especially remarkable in the Mancha Occidental aquifer, a large, over-drafted aquifer extending over $5000 \mathrm{~km}^{2}$ situated in the inland central region of Castilla-La Mancha in the Upper Guadiana river basin. The area presents a continental semiarid climate, with an average annual rainfall of $415 \mathrm{~mm}$, an average annual temperature of $15^{\circ} \mathrm{C}$, and potential evapotranspiration rates on the order of $1000 \mathrm{~mm} /$ year ( $\mathrm{CHG}, 2007$ ).

As a consequence of the legal declaration of overexploitation of the Mancha Occidental Aquifer in 1987, water authorities implemented pursued the constitution of groundwater user associations and the Water Abstraction Plans (WAP). Typically, these were imposed using a top-down approach. The 
Table 1

Water Abstraction Plan (2007)

\begin{tabular}{ll}
\hline Farm size (ha) & Water quotas $\left(\mathrm{m}^{3} / \mathrm{ha}\right)$ \\
\hline $0-30$ & 2640 \\
$30-80$ & 2000 \\
$>80$ & 1200 \\
Vineyard & 1000 \\
\hline
\end{tabular}

$\mathrm{CHG}(2006)$

WAP forbade drilling new wells or deepening the existing ones, and limited annual water abstractions by means of a quota system based on farm size, with no compensation (see Table 1).

This program was implemented without the agreement of the farmers, who are the main water users, and has faced strong social opposition ever since (Schlager and López-Gunn, 2006; VarelaOrtega and Blanco, 2008). The nearly non-existent institutional arrangements between the regional government, water authorities and water users themselves, and the high enforcement cost of controlling water abstractions for agricultural irrigation have led to the continued exploitation of the aquifer, proliferation of numerous unlicensed wells, and generation of environmental externalities derived from degradation of the valuable wetlands ecosystems associated with the aquifer in 'Tablas de Daimiel' National Park (Martínez-Santos et al., 2008). Official sources estimate that presently, nearly $50 \%$ of the wells in the Mancha Occidental aquifer are unlicensed (approximately 20,000 wells) and total water abstractions greatly exceed the Natural Recharge Rate (NRR) of the aquifer, estimated to be around $230-240 \mathrm{Mm}^{3} /$ year ( $\mathrm{CHG}, 2007$ ). The intensive pumping for irrigated agriculture caused noteworthy water table drawdowns (of about $1 \mathrm{~m} /$ year), resulting in a reduction of the flooded wetland area from 1800 ha to $200 \mathrm{ha}$ over the past 30 years.

This situation is not sustainable and contradicts the European Water Framework Directive (WFD) (EC, 2000), which proclaims the protection of water resources and aims at achieving 'good ecological status' for all water bodies by 2015 . The Directive establishes a river basin management approach and requires the elaboration, including public consultation, of six year ly river basin management plans and a program of measures starting in 2009 (articles 11, 13 . 14). A program of measures must include the implementation of water-pricing policies by 2010 to provide adequate incentives to use water more efficiently and contribute to the recovery of the cost of all water services, including environmental and resources costs (article 9). Moreover, the WFD suggests that a cost-effectiveness analysis (CEA) should be performed in order to achieve the Directive's goals at lowest cost (Annex [l], WATECO, 2002). This analysis is key when selecting alternative measures and identifying excessive costs that could justify lower objectives as well as the postponement of the fulfillment of the Directive's objectives (article 4 of the WFD). Nevertheless, the Directive hardly describes how to proceed with the CEA and only a few Northern European countries have developed consistent evaluation methods so far. Most of the reviewed cost-effectiveness methods have a strong focus on water quality issues and consider the river basin scale as an indivisible and unique unit for analysis (see for instance, Interwies et al., 2004 for the Germany context, and Postle et al., 2004 for the UK context).

The WFD principles and instruments have already been partially contemplated in the Special Plan for the Upper Guadiana (SPUG), recently approved by the Spanish parliament ( $\mathrm{CHG}, 2007$ ), and they will be reflected in the new Guadiana river basin water management plan by 2010 . The SPUG aims at establishing sustainable water use in the Uррег Guadiana basin by 2027 , strengthens the participation of the stakeholders in water management and introduces innovative conservation measures for recovering the Mancha
Occidental aquifer. These measures include campaigns for purchasing irrigation water rights (although some of the recovered water volume will be subsequently returned to irrigators for legalizing some un-licensed wells); strict regulations to control groundwater overdrafts and close up unlicensed wells; a reforestation plan; and complementary measures for promoting rainfed agriculture and the cultivation of less water-intensive crops in the area ( $\mathrm{CHG}$, 2007).

In conclusion, the revision of the current water policies and application of new cost-effective and environmentally sensitive policy instruments which guarantee efficient public participation in water management processes is one of the major tasks that must be addressed by water managers and policy makers in Spain, and especially in the Upper Guadiana basin. This paper contributes to this debate, evaluating the cost-effectiveness of alternative water conservation policies that may reduce water consumption in the Mancha Occidental aquifer and, ultimately, promote sustainable groundwater management in the Upper Guadiana basin.

In Section 2, we revise numerous studies that have investigated alternative groundwater management instruments, their advantages and disadvantages. Howeve $r_{+}$little attention has been focused on the comparative assessment of the cost and effectiveness of different instruments, and rarely has this analysis been made on water quantity issues at different spatial scales. One of the key aspects of our methodology is the development of a reproducible multiscale economic optimization model able to assess environmental and socio-economic policy impacts at different spatial scales (at farm and sub-basin level).

\section{Theoretical background: policy instruments for groundwater management}

Groundwater is considered a 'common pool resource' (rival and non-excludable good) and its overexploitation is often explained by the model of the Tragedy of the Commons set forth by Hardin (1968). Following his model, individual users tend to maximize their water consumption, ignoring the impact of their extractions on future water levels. The incentive for any individual is to free-ride on the benefits from conservative behavior by the others (Olson, 1965). Consequently, the extraction rate reached is higher than the optimum social rate, resulting in collective inefficiencies and groundwater overexploitation (Feinerman, 1988; Gordon, 1954). In most cases, this disparity is due to lack of regulation or insufficient dynamism of the existing institutional arrangements (Millimam, 1956; Schlager and López-Gunn, 2006).

Numerous studies have investigated the use of policy instruments to regulate groundwater withdrawals and promote more efficient groundwater use. Since agriculture constitutes the main use of water in arid and semi-arid countries, most of these studjes focus on the potential of water conservation instruments in irrigation water management. Water use quota systems are likely the most widely employed regulatory instruments in controlling groundwater pumping and water consumption for irrigation (Koundouri, 2004). These mechanisms allow equity issues to be taken into consideration and promote transparent reallocation of water (Johansson et al., 2002; Wichelns, 1999). Nevertheless, some authors (such as Dinar et al., 1997; Molle, 2009; Rogers et al., 2002; among others) cast doubts on the establishment of quota allotments or water use rights as being too inflexible to adapt to changing conditions. They furthermore warn of the high costs of monitoring processes and measurement controls which would be incurred if water quotas are not socially accepted following a bottom-up design approach. 
Administered pricing policies are also policy instruments commonly analyzed in the literature for their water-saving potential and their reputation as appropriate cost-recovery mechanisms (Bazzani et al., 2005; Gómez-Limón and Rjesgo, 2004; Molle and Berkoff, 2007; Tsur et al., 2004; Varela-Ortega et al., 1998; among others). Rogers et al. (2002) argue that, when water scarcity becomes a leading issue, pricing policies may increase efficiency in water management as well as improve water reallocation, equity and sustainability. However, in spite of their popularity, their application remains controversial, especially in developing countries. Many studies (see e.g. Cornish et al., 2004; De Fraiture and Perry, 2007; Molle et al., 2008) indicate that substantial price increases are required to induce water saving, which might increase farmers' financial vulnerability and endanger the social acceptability and political feasibility of water pricing policies. Thus, Chohin-kuper et al. (2003) and Molle (2009) state that centralized water prices are actually more often used to recover water costs than to reduce water consumption, even when water scarcity is high.

The last two decades witnessed the resurgence of decentralized water management schemes to improve water efficiency and confront increasing conflicts among water users (Dinar and Subramanian, 1997; Johansson et al., 2002; Zekri and Easter, 2005). Easter et al. (1998) discuss the potential of water markets in a wide variety of contexts and argue that, when transaction costs are low, these instruments may provide better water allocation efficiency and higher economic benefits than other regulatory approaches. Nevertheless, there are numerous conditions necessary to hold down transaction costs, and several studies show that in realworld contexts the apparent superiority of water markets is limited (see Garrido and Calatrava, 2010; Johansson et al., 2002; Kemper, 2001; Koundouri, 2004; Rosegrant and Schleyer, 1996; among others).
Feinerman (1988) claims that in terms of water use efficiency no single ground water management tool is clearly superior to another. Feinerman's study also states that equity aspects (i.e. wealth distribution among individual users) are as important as efficiency issues. Past experiences show that the most efficient tool, in economic terms, may not be the most suitable solution. Dinar et al. (1997) conclude that no single economic instrument can work in all situations.

There are still many uncertainties about the potential of water quotas, water pricing and water markets for groundwater demand management. The existing studies about the use of economic instruments in irrigation water management are limited to specific local conditions, both physically and institutionally (Bjornlund et al., 2007). Therefore, more investigations are needed to provide new insights and transferable empirical experiences.

\section{Analytical framework}

\subsection{Methodological overview}

The methodology adopted for this research is represented schematically in Fig. 1. A detailed step-by-step description of the analytical procedures is presented after this figure.

- Step 1: Creation of a knowledge base. This step comprises the site-specific characterization of the study area, selection of the representative farms, and estimation of the model's input coefficients and parameters. It is based on fieldwork, statistical data collection, and stakeholder consultation.

- Step 2: Development of a non-linear Mathematical Programming Model (MPM) of constrained optimization to simulate farmers' behavior under different policy scenarios and risk situations.

\section{Creation of a knowledge base}

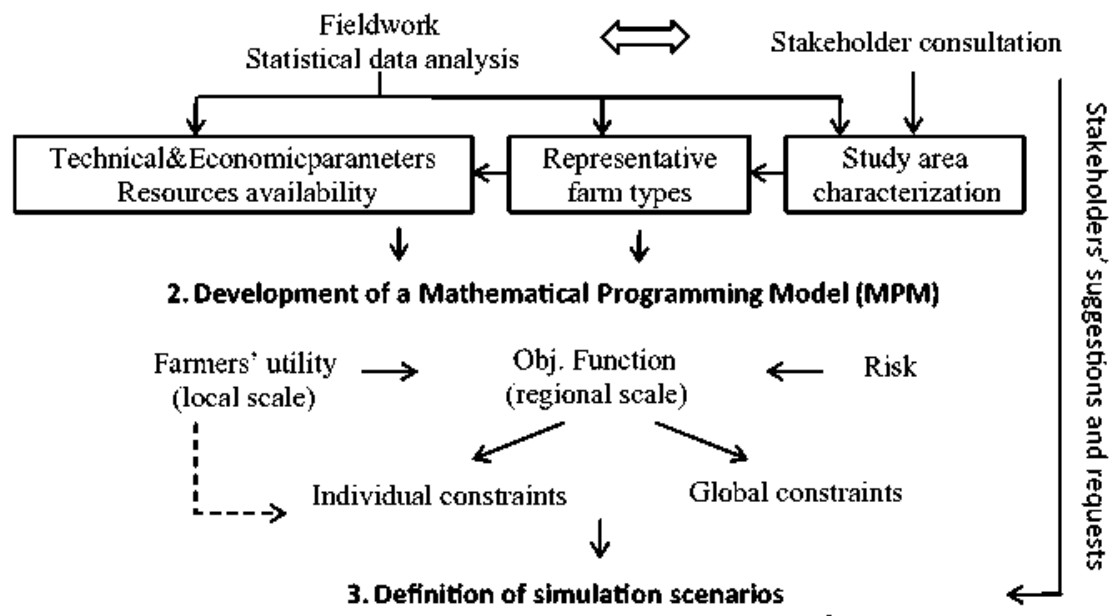

Group $A$

Obj.: Controlling illegal water drilling

-Closure of unlicensed wells

-Taxed legalization of unlicensed wells
Obj: : Reducing irrigation groundwater use

-Water Pricing (uniform\&block-rate)

-New water quotas system -Water market

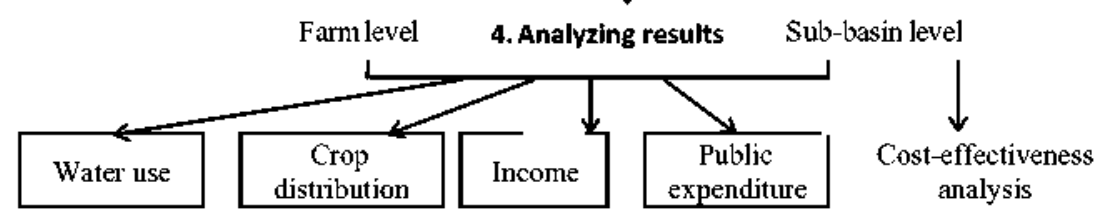

Fig. 1. Methodological overview. 
- Step 3: Definition of simulation scenarios, based on literature review and stakeholders' suggestions. They includes policies devised to control illegal water drilling in the aquifer of study (Group A), and water management policies designed to reduce groundwater consumption for irrigation (Group B).

- Step 4: Results and cost-effectiveness analysis. A set of multi-level indicators was used to represent the economic, social and environmental performances of the Mancha Occidental's agricultural systems at the farm level and sub-basin levels (Upper Guadiana basin).

\subsection{Creation of a knowledge base}

Farms are considered the basic unit of analysis in agriculture. However, modeling agricultural systems confronted with environmental issues usually requires integrating farm-scales with regional-scales. In this research, the zone of study has been characterized using typologies of farms aggregated at regional scale. Typologies have been widely used for representing the complexity of farmers' systems in different Spanish irrigation communities (Arriaza et al., 2002; Bjornlund et al., 2007; Gómez-Limón and Riesgo, 2004; Iglesias and Blanco, 2008; Varela-Ortega et al., 1998). Maton et al. (2005) and Poussin et al. (2008) review different methods to build typologies. Based on their findings, the "positivist method" was selected and applied to this study. First, a statistical analysis of official data was performed to study the characteristics of the regional agricultural production in the area overlying the Mancha Occidental aquifer and to determine the structural characteristics of the representative farm types. This information was collected from regional and national Government sources as well as from the Guadiana River Basin Authority publications. Subsequently, farm typologies were completed by targeted fieldwork surveys ( 30 in total) and personal interviews with the stakeholders (mainly local experts and irrigation communities). Finally, farm typologies were clustered according to structural criteria in order to obtain homogeneous groups with similar production systems.

As shown in Table 2, the study region (the Mancha Occidental aquifer) has been identified as a weighted (by surface) sum of four representative farm types (F1, F2, F3 and F4). Each 'farm type' is considered an aggregation of homogeneous types of agri- cultural production systems in terms of growing surface, type of wells, water use, soil quality, and crop distribution.

The Mancha Occidental aquifer covers about 400,000 cultivated hectares. Irrigated surface spans an area of 182,000 ha ( $46 \%$ of the total cultivated area), from which almost 60,000 are allegedly being irrigated from unlicensed wells. The farm types F1 and F2 represent fully irrigated agricultural systems in which licensed and unlicensed wells coexist and water consumption rates exceed the water abstraction quotas imposed by the Guadiana River Basin Authority. These production systems are concentrated in smallmedium holdings with good soil qualities and high value-added crops, such us vegetables and irrigated vineyards which, being difficult to map using satellite imagery, are often illegally irrigated. On the other hand, the average size of farms F3 and F4 is larger. These farms have more diversified crops (barley, wheat, maize, vegetables, and vineyards) than the farm F2, and combine rainfed and irrigated agricultural productions in different soil qualities. Only licensed wells are used to pump water for irrigation, though they also use more water than that allowed by the WAP. As we are considering the cost of compliance with the WFD, which includes the environmental costs related to the aquifer's degradation, we have not selected any completely 'legal' representative farm (that is, a farm that complies with the WAP and has no unlicensed wells), although they also exist in the region.

\subsection{Development of a Mathematical Programming Model}

The model used to perform this analysis is a non-linear singleyear static MPM of constraint optimization defined at regional scale (sub-basin aggregation). It complements previous modeling work developed by [glesias (2002), Varela-Ortega (2007), and VarelaOrtega et al. (1998) at plot scale in the same area of study.

According to the expected utility theory of Von Neuman and Morgenstern (1994), farmers are considered rational and selfinterested individuals with well ordered preferences that try to maximize their utility choosing among alternative farm plans. In the present study, the model maximizes a utility function subject to land, labor, water, and policy constraints. The utility function is defined by a profit function and a risk vector that takes into account climate as well as market prices variations (see Appendix A for detailed specifications). Several studies (such as Ellis, 1993; Huirne

Table 2

Representative tarim types.

\begin{tabular}{|c|c|c|c|c|c|}
\hline \multirow[t]{2}{*}{ Characteristics } & \multicolumn{4}{|c|}{ Representative farms } & \multirow[t]{2}{*}{ Aquifer } \\
\hline & F1 & $\mathrm{F} 2$ & $\mathrm{~F} 3$ & $\mathrm{~F} 4$ & \\
\hline Total growing surface (ha) & 56.667 & 55,254 & 38,838 & 76,741 & 227,500 \\
\hline Average tarm size & 10 (very simall) & 35 (medium) & 75 (big) & 265 (very big) & 23 \\
\hline Irrigated surface (\%) & 100 & 100 & 80 & 50 & 80 \\
\hline \multicolumn{6}{|l|}{ Water use ( $\left.\mathrm{m}^{3} / \mathrm{ha}\right)$} \\
\hline Water quotas & 2220 & 1500 & 1600 & 1000 & 1527 \\
\hline Actual water consumption ${ }^{b}$ & 3390 & 1906 & 2371 & 2371 & 2514 \\
\hline Number of wells & 12,401 & 18,266 & 3824 & 4723 & 39,214 \\
\hline Licensed Junlicensed (\%) & $61 / 39$ & $13 / 87$ & $100 / 0$ & $100 j 0$ & $40 / 60$ \\
\hline Irtigated hectares per well & 4 & 3 & 8 & 8 & 5 \\
\hline Soil type (bad/good soil) & $39 / 61$ & $20 / 80$ & $5 8 \longdiv { 4 2 }$ & $80 / 20$ & $51 / 49$ \\
\hline \multicolumn{6}{|l|}{ Crop distribution (\%) } \\
\hline (ereals (barley, wheat) & 30.0 & 18.0 & 45 & 63.7 & 41.0 \\
\hline Maize & 0.0 & 0.0 & 2.0 & 0.3 & 0.4 \\
\hline Vegetables & 30.0 & 5.0 & 14.0 & 10.0 & 14.5 \\
\hline Vineyald & 30.0 & 75.0 & 28.0 & 10.0 & 33.8 \\
\hline Set-aside & 10.0 & 2.0 & 11.0 & 16.0 & 10.3 \\
\hline Total area $(x)$ & 100 & 100 & 100 & 100 & 100 \\
\hline Surface weight (\%) & 25 & 24 & 17 & 34 & 100 \\
\hline
\end{tabular}

Own elaboration based on official stat istics (CHC, 2007; IES, 2006) and farmers' surveys (2005 and 2006 ).

a Water quotas established by the WAP (CHG, 2006).

- Actual water consumption is calculated based on the prevailing crop distribution and cortesponding crop water requirements.

c This is an estimate of the total number of wells. The number of wells actually in use is knowin (around 8000 ). 
Table 3

Simulated policy scenarios.

\begin{tabular}{|c|c|c|c|c|}
\hline \multirow{3}{*}{$\begin{array}{l}\text { Group of } \\
\text { scenarios }\end{array}$} & \multirow[t]{3}{*}{ Objective } & \multicolumn{2}{|c|}{ Simulated policy scenarios } & \multirow{3}{*}{$\begin{array}{l}\text { Description of simulated policy } \\
\text { scenarios }\end{array}$} \\
\hline & & \multicolumn{2}{|c|}{ Policy options for managing. . . } & \\
\hline & & Unlicensed watel use ${ }^{3}$ & Licensed water use ${ }^{\mathbf{a}}$ & \\
\hline$A$ & $\begin{array}{l}\text { Regulatory objective: Controlling } \\
\text { illegal groundwater consumption }{ }^{b}\end{array}$ & $\begin{array}{l}\text { Closure of unlicensed } \\
\text { wells } \\
\text { Taxed legalization of } \\
\text { unlicensed wells }\end{array}$ & $\begin{array}{l}\text { Prevailing water quota } \\
\text { system (WAP) }\end{array}$ & $\begin{array}{l}\text { Fierce control of groundwater } \\
\text { over-drafts: } \\
\text { - licensed extractions respect the WAP } \\
\text { - all unlicensed wells are closed-up } \\
\text { Modelate control of groundwater } \\
\text { over-drafts: } \\
\text { - licensed extractions respect the WAP } \\
\text { - unlicensed wells are legalized by } \\
\text { paying an entry right fee of } 6000 € \text { per } \\
\text { intigated liectarec }\end{array}$ \\
\hline \multirow[t]{3}{*}{ B } & $\begin{array}{l}\text { Environmental objective: } \\
\text { Reducing irtigation ground water } \\
\text { consumption to assure the } \\
\text { aquifer's recliatge }\end{array}$ & $\begin{array}{l}\text { Taxed legalization of } \\
\text { unlicensed wells }\end{array}$ & $\begin{array}{l}\text { Uniform water pricing } \\
\text { Block-rate water } \\
\text { pricing }\end{array}$ & 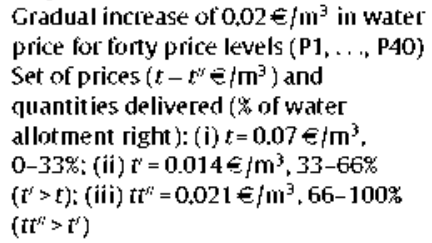 \\
\hline & & & $\begin{array}{l}\text { New water quota } \\
\text { system }\end{array}$ & $\begin{array}{l}\text { Non-tradable groundwater extraction } \\
\text { rights (equally dist ributed per hectare } \\
\text { of irrigated surface). Total water } \\
\text { abstractions are limited to the NRR of } \\
\text { the aquiter. }\end{array}$ \\
\hline & & & Water rights market & $\begin{array}{l}\text { Previous administered water use rights } \\
\text { are exchanged. The matket equilibtium } \\
\text { price is set using the dual values of the } \\
\text { preceding simulation results (news } \\
\text { water quota system scenario). } \\
\text { Transaction costs of } 5 \% \text { are considered. }\end{array}$ \\
\hline
\end{tabular}

a From now on, 'unlicensed water use' refers to the water extracted from unlicensed wells and 'licensed water use' reters to the water extracted firom licensed wells.

b Illegal grou indwater consumption' comprises the watel pumped from unlicensed wells and the water consumed over the quotas established by the WaP.

c This policy option is contemplated in the recently approved SPUC; (CHG, 2007).

et al., 2000; Hardaker et al., 2004) provide empirical evidence that risk and uncertainty situations generate income instability, affecting farmer decision-making. In that regard, Friedman and Savage (1948) demonstrate that farmers are usually 'risk averse' (do not wish to take risks) and, therefore, they tend to choose less-risky alternatives even if that requires renouncing part of their potential income.

In particular, the economic model developed to undertake this analysis optimize the regional expected utility, as an aggregation of the expected utilities of the four farm types, while keeping the specificity of individual constraints. This twofold characteristic of the model facilitates the mobility of water resources among the different farm types, permits the up-scaling of farm-based results at the sub-basin aquifer level, and allows analyzing the complex social, physical, and economic interactions between legal and illegal groundwater uses in a more integrated way. Similar multiscale programming models have been recently developed by Alary and Deybe (2005), Flichman et al. (2006), Henseler et al. (2009), Medellin-Azuara et al. (2010), and Rounsevell et al. (2003), for integrated regional analysis. These studies indicate that different farms can be aggregated at regional level and represented by a unique MPM under conditions of homogeneity. Day (1963) and Buckwell and Hazell (1972) demonstrate that technologically homogeneous and pecuniously and institutionally proportional farms (i.e., farms with the same possibilities of production, agroclimatic conditions, levels of technology, availability of resources, management capacity, etc.) can be grouped together with relatively small problems of aggregation bias. In addition, Gómez-Limón and Riesgo (2004), indicate that, when decisions are based on the same decisionmaking criteria (in our case, the utility's maximization), farm types can be modeled by means of a unique MPM.
The model was calibrated with the risk-aversion coefficient ${ }^{1}$ and validated using the Percentage Absolute Deviation ${ }^{2}$ (PAD) parameter to verify the actual crop distribution (main decision-making variable in the model) in each farm type. PAD values range from $3.5 \%$ to $16 \%$, which are below the threshold value of $20 \%$ that determines the rejection of a model (Hazell and Norton, 1986, p. 271).

\subsection{Simulation scenarios}

Foster and Chilton (2003) and Tuinhof et al. (2003) identified different hydraulic stress stages of groundwater resource development analyzing the impacts of abstraction rates and proliferation of wells over time. The critical situation of the Mancha Occidental aquifer could be associated with a stage of "unstable groundwater development' in which inaction might lead to an irreversible degradation of the aquifer and severe social conflicts among stakeholders. To avoid this undesirable outcome, the combination of an adequate regulatory framework with water demand management policies has been highly recommended by water experts (e.g. Dinar et al., 1997; Kemper, 2007; Tuinhof et al., 2003). Following these recommendations, different policy options were combined to, first, control illegal water consumption (as a base of an appropriate regulatory framework) (group of policy scenarios A), and second, reduce groundwater demand for irrigation to comply with the WFD's envi-

\footnotetext{
1 The risk aversion parameter selected was 1.65. It indicates that the probability to have an income higher or equal to $Z$ is $95 \%$ with an error of the lrypotheses test lower to 5\%.

${ }^{2} \operatorname{PAD}(\%)=\sum_{c-i t}^{n}\left|\overline{X_{c}}-X_{c}\right| \cdot 100 / \sum_{c-i t}^{n} \overline{X_{i}}: \overline{X_{c}} \div$ observed sutface: $X_{c}:$ simulated
} surface. 


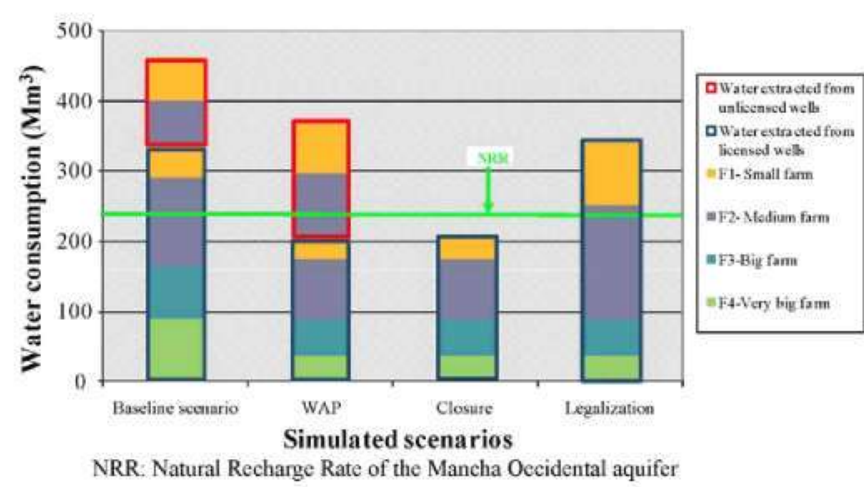

Fig. 2. Water consumption for irrigation in the Mancha Occidental Aquifer under different policy scenarios for eliminating groundwater overdraft.

ronmental objectives (group of policy scenarios B). ${ }^{3}$ Table 3 briefly summarizes the simulated policy scenarios.

To accomplish the first objective, the authors evaluate alternative policy options for eliminating 'unlicensed water use' (primary cause of 'illegal groundwater consumption') under the assumption that the current WAP is still in place. To reach the second objective, the cost and effectiveness of alternative water demand management policies are analyzed, assuming that all unlicensed wells have been previously legalized.

The different policy and management options were selected based on a review of the literature (see Section 2) and stakeholders' requests. Several stakeholder meetings were held as part of a participatory process conducted from 2005 to 2008 within the framework of the NeWater project. ${ }^{4}$ In particular, three stakeholder meetings, thematically oriented around economic, hydrological and institutional aspects of irrigation groundwater management, served as basis for scenario building. ${ }^{5}$ Each meeting was attended by roughly 25 stakeholders from different groups: farmers, irrigation communities, environmental conservation groups, regional departments (of environment and agriculture), Guadiana River Basin Authority, etc.

Throughout the consultation process, stakeholders were encouraged to suggest, explicitly for the study area, different water management policies which might potentially reach the goal of aquifer sustainability. Stakeholders' suggestions basically stressed the reform of the on-going water policies and the implementation of new water management options (Varela-Ortega, in revision). The current WAP is highly criticized by farmers for restricting their historical water rights $\left(4280 \mathrm{~m}^{3} / \mathrm{ha}\right)$ and establishing differentiated water quotas according to the cropping distribution and farms' surface, which created unpleasant frictions between small and large landowners-irrigators. Thus, stakeholders were very interested in exploring the cost and effectiveness of a more equitable water quota system and new decentralized water policies, such as the establishment of water pricing schemes or a water rights market. It is worth mentioning that discrepancies arose among stakeholders when discussing the best option for eliminating unlicensed groundwater use (Martínez-Santos et al., 2010). While the environmental conservation groups request a strict application of the law and ask

\footnotetext{
${ }^{3}$ All wells are equipped with groundwater metering devices. We assume that water consumption can be fully metered.

${ }^{4}$ NeWater(New Approaches to Adaptive Water Management under Uncertainty) is a 4-year (2005-2009) Integrated Project funded by the European Union's 6th Framework Research Program ( $n^{\circ}$ : FP6-2003-GLOBAL-2-SUSTDEV-6.3.2 - 5111792) (www.newater.info).

5 Detailed information about the development and main results of the stakeholder consultation process are provided by Martínez-Santos et al. (2008, 2010), VarelaOrtega (in revision), and Zorrilla et al. (2010).
}

for fining of illegal pumpers as well as closing up all unlicensed wells, the irrigators suggested a 'second chance' and advocate for finding an agreement with the government that will allow them to register their unlicensed wells. In between these disparate view points, the Guadiana River Basin authority, which is the agency responsible for water management in the basin, is urged to enforce the law and close-up unlicensed wells, but has no means by which to do so and prefers to avoid such an unpopular and costly task.

\section{Simulation results and discussion}

\subsection{The open access problem: strengthening of groundwater regulatory framework}

The baseline scenario ${ }^{6}$ represents the current situation of the Mancha Occidental aquifer, in which total groundwater abstractions ( $460 \mathrm{Mm}^{3}$ ) largely exceeds the NRR of the aquifer $\left(240 \mathrm{Mm}^{3}\right)$. Irrigators do not comply with the existing water quota regime (WAP) ${ }^{7}$ imposed by the Guadiana River Basin Authority to recover the exhausted aquifer $\left(335 \mathrm{Mm}^{3}\right.$ of water for agriculture is extracted from licensed wells), neither respect the prohibition to extract water from unlicensed wells (approximately, $127 \mathrm{Mm}^{3}$ of water is illicitly extracted). Fig. 2 shows the impact on total groundwater consumption of the application of different policy options for eliminating groundwater overdrafts in the Mancha Occidental aquifer.

The simulation results indicate that any attempt to restrain 'licensed water abstractions' (water extracted from licensed wells), e.g. through a strict enforcement of the current WAP, would be ineffective unless 'unlicensed water abstractions' (water extracted from unlicensed wells) are previously controlled. As evidenced in Fig. 2 (WAP scenario), farms in which legal and illegal wells coexist (such as, the small and medium farms F1 and F2) would try to intensify their water abstractions from unlicensed wells to compensate their losses for complying with the WAP. Consequently, total water consumption in the aquifer would be only slightly reduced (from $460 \mathrm{Mm}^{3}$ to $370 \mathrm{Mm}^{3}$ ). Experiences from the past suggest that this situation might provoke a heavy clash between 'legal' and 'illegal' irrigators, increasing the already existing social tensions and free-riding behaviors in the region (Martínez-Santos et al., 2008; Varela-Ortega, 2007). Thus, overcoming groundwater overdrafting would require an effective combination of measures addressed to control water consumption and halting illegal drilling at the same time. Table 4 shows the model results of the WAP scenario and the application of alternative policy options (closure and legalization of unlicensed wells) for controlling 'unlicensed water abstractions', assuming that all irrigators comply with the current WAP. Disaggregated results on water consumption farm income, public revenue collection and expenditure, and crop distribution are displayed in Table 4 . In the present study, the net public expenditure is calculated as the gross public expenditure minus the public collection. Public collection refers to water fees and charges collected by the water authority (basically, water use tariffs, taxes per well, and taxes paid for registering the unlicensed wells), whereas the gross public expenditure comprises the CAP subsidy payments for crops and land paid by the government and will mainly depend on the cropping distribution of the farms.

Closing up unlicensed wells would, in fact, reduce irrigation groundwater consumption to a volume compatible with the sus-

\footnotetext{
${ }^{6}$ The prevailing situation of the Mancha Occidental aquifer in 2007 is considered the baseline scenario or reference situation.

7 The WAP establishes a maximum water volume of $200 \mathrm{Mm}^{3}$ to be yearly diverted to the agricultural sector (CHG, 2006). The structure of the WAP water quotas is shown in Table 1 . Table 2 includes the WAP water quotas by representative farm.
} 
Table 4

Effects of different policy options for eliminating groundwater overdrafts in the Mancha Occidental aquifer.

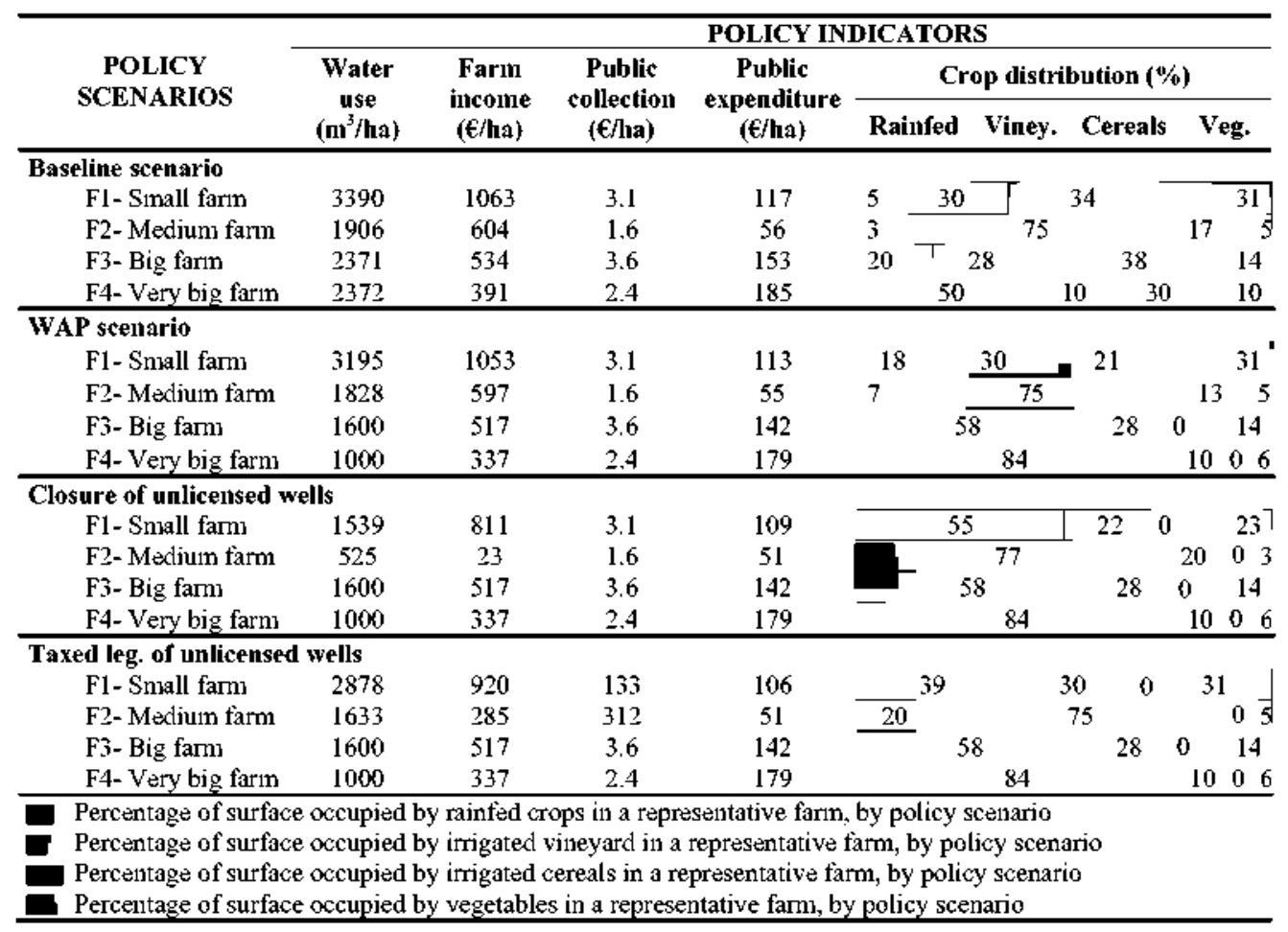

tainable management of the aquifer (approximately $200 \mathrm{Mm}^{3}$ ) (see Fig. 2). However, the enforcement of such policy seems problematic due on one hand, to the large transaction costs in which public authorities would incur to close the large number of unlicensed wells and to the other hand, to the high income losses inflicted upon some farmers. As we can see in Table 4, the medium farm F2 would see its income gains reduced by $96 \%$ (from 604 to $23 € /$ ha), as a consequence of a major shift from irrigated to rainfed agriculture with less economic profitability (74\% of the total irrigated surface, mainly vineyard, would be transformed into rainfed cropland). Two main reasons can explain this switch in land use: first, obviously, is the strong reduction in water consumption (from 1906 to $525 \mathrm{~m}^{3} /$ ha, see Table 4) caused by the closure of wells (almost $60 \%$ of the water used by the farm F2 is pumped from unlicensed wells); and second is the low crop diversification potential of the farm in question. Irrigated vineyard spans over $75 \%$ of the farm's growing surface, limiting the possibility of adjusting the cropping pattern within the farm to reduce water consumption in the shortterm. In that regard, Martinez-Santos et al. (2008) indicate that there are not many other lucrative and water-efficient crops to be used as alternatives to irrigated vineyards in the area.

On the other hand, Table 4 shows that the legalization of unlicensed wells would entail milder income losses to farms F1 and F2 (15\% and $47 \%$, respectively) and would preserve irrigated vineyards and vegetables. From the public point of view, the model results indicate that public expenditure is almost equivalent in all simulated scenarios. However, public collection would greatly increase in the legalization scenario (from 2.5 to 110 / ha on average) because of the taxes collected by the water authority for registering unlicensed wells, offsetting gross public expenditure in farms F1 and F2. Notwithstanding the positive aspects of the legalization of unlicensed wells in comparison to the closing up scenario, this policy option would trim down groundwater use for irrigation to $340 \mathrm{Mm}^{3}$, but would not guarantee the sustainability of the Mancha Occidental aquifer (see Fig. 2). For accomplishing the environmental objective the prevailing WAP, which constrained only the 'licensed groundwater use', should now be transformed in such a way that the water quotas also include the water extracted from the new legalized wells. In Section 4.2, a new water quota system is analyzed, as well as other groundwater demand instruments for reducing water consumption.

\subsection{The role of water management policies to achieve conservation goals}

This section shows a selection of the results obtained in the simulation of policy scenarios aiming at reducing irrigation groundwater consumption (to $240 \mathrm{Mm}^{3}$ ) to assure the aquifer's sustainability. Table 5 shows the model results of the application of alternative water management policies, under the assumption that all unlicensed wells have been previously legalized. Disaggregated results on the environment ( water consumption and crop distribution), private sector (farm income), and public sector (government revenue collection and expenditure) are displayed in Table 5.

\subsubsection{Water pricing}

Groundwater irrigation farmers usually pay the full financial cost of groundwater use (capital costs and maintenance and operation costs), however seldom assume the environmental and resource costs of groundwater abstractions (Garrido et al., 2006; Llamas and Martínez-Santos, 2005; Shah et al., 2007). The national report from the Spanish Ministry of the Environment on water pricing and cost recovery in Spain (MMA, 2007) points out that in the Guadiana basin, the average financial cost of groundwater services is $0.10 € / \mathrm{m}^{3}$ with a cost recovery level among agricultural users of 90-100\%. Garrido and Calatrava (2010) state that water tariffs should be doubled if environmental costs are included in the water services costs. In the Mancha Occidental aquifer, irrigators already pay the full economic cost of groundwater abstractions, estimated to be $0.08 € / \mathrm{m}^{3}$. As evidenced in Fig. 3, our findings indicate that additional water tariffs, ranging between 0.11 and $0.21 € / \mathrm{m}^{3}$. should be implemented in the Mancha Occidental aquifer for fully 
Table 5

Effects of water management policies for promoting sustainable groundwater use in the Mancha Occidental aquifer.

\begin{tabular}{|c|c|c|c|c|c|c|}
\hline \multirow[t]{3}{*}{ Policy scenarios } & \multicolumn{6}{|l|}{ Policy indicators } \\
\hline & \multirow[t]{2}{*}{ Water consumption ( $\left.\mathrm{m}^{3} / \mathrm{ha}\right)$} & \multirow[t]{2}{*}{ Farm income ( $€ /$ ha) } & \multirow[t]{2}{*}{ Public collection ( $€ /$ ha) } & \multirow[t]{2}{*}{ Public expenditure ( $\in / \mathrm{ha})$} & \multicolumn{2}{|c|}{ Crop distribution (\%) } \\
\hline & & & & & Rainfed & Irrigated \\
\hline \multicolumn{7}{|l|}{ Baseline scenario } \\
\hline F1: Small farm & 3390 & 1063 & 3.1 & 117 & 5 & 95 \\
\hline F2: Medium farm & 1906 & 604 & 1.6 & 56 & 3 & 97 \\
\hline F3: Big farm & 2371 & 534 & 3.6 & 153 & 20 & 80 \\
\hline F4: Very big farm & 2372 & 391 & 2.4 & 185 & 50 & 50 \\
\hline \multicolumn{7}{|c|}{ Uniform w. pricing $\left(P^{1}=0.21 \in / \mathrm{m}^{3}\right)$} \\
\hline F1: Small farm & 1079 & 496 & 273 & 113 & 59 & 41 \\
\hline F2: Medium farm & 1592 & -43 & 637 & 51 & 20 & 80 \\
\hline F3: Big farm & 1469 & 255 & 250 & 142 & 59 & 41 \\
\hline F4: Very big farm & 1242 & 232 & 133 & 178 & 81 & 19 \\
\hline \multicolumn{7}{|c|}{ Block w. pricing $\left(P^{2}=0.11 \in / \mathrm{m}^{3}\right)$} \\
\hline F1: Small farm & 1079 & 612 & 156 & 113 & 59 & 41 \\
\hline F2: Medium farm & 1592 & 87 & 507 & 50 & 20 & 80 \\
\hline F3: Big farm & 1469 & 386 & 120 & 142 & 59 & 41 \\
\hline F4: Very big farm & 1242 & 294 & 71 & 178 & 81 & 19 \\
\hline \multicolumn{7}{|l|}{ Water use quota } \\
\hline F1: Small farm & 1337 & 775 & 46 & 111 & 54 & 46 \\
\hline F2: Medium farm & 1337 & 235 & 299 & 52 & 26 & 74 \\
\hline F3: Big farm & 1337 & 480 & 3.6 & 142 & 61 & 39 \\
\hline F4: Very big farm & 1337 & 372 & 2.2 & 178 & 80 & 20 \\
\hline \multicolumn{7}{|c|}{ Water markets $\left(P^{3}=0.24 € / \mathrm{m}^{3}\right)$} \\
\hline F1: Small farm & 1337 & 775 & 46 & 111 & 54 & 46 \\
\hline F2: Medium farm & 1351 & 236 & 303 & 52 & 25 & 75 \\
\hline F3: Big farm & 1337 & 480 & 4.5 & 142 & 61 & 39 \\
\hline F4: Very big farm & 1315 & 373 & 4.5 & 178 & 81 & 19 \\
\hline
\end{tabular}

recovering the environmental costs associated to the aquifer's degradation. These levels of water tariffs reduce groundwater consumption to $240 \mathrm{Mm}^{3}$ (equivalent to the NRR of the aquifer) and therefore, they promote the recovery of the aquifer, which is essential for the restoration of the valuable groundwater-dependent wetland ecosystems of the Tablas de Daimiel National Park. Based on the 'replacement cost method' (Turner et al., 2004), the water prices needed to achieve the environmental target of the aquifer's conservation were used to measure the environmental costs associated with the use of ground water for irrigation. The aggregate water demand response for the two types of selected price schemes (uniform volumetric and block-rate water pricing) is shown in Fig. 3.

The model results indicate that block-rate tariffs are more water saving than uniform tariffs. In other words, higher water prices would be needed with a uniform volumetric water pricing system to reduce groundwater consumption to $240 \mathrm{Mm}^{3}$. As we can see in Fig. 3, it would be necessary to apply a uniform tariff of $0.21 \mathrm{e} / \mathrm{m}^{3}$ to achieve the desired reduction in groundwater consumption, whereas a lower block-rate tariff of $0.11 € / \mathrm{m}^{3}$ would be enough to accomplish the same objective.

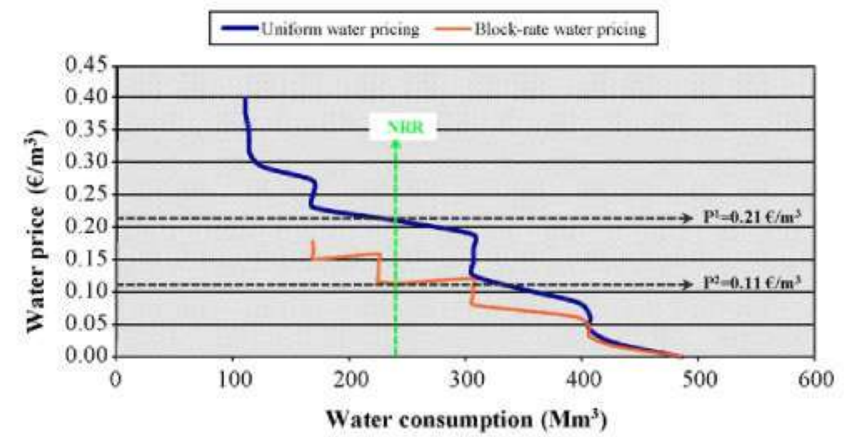

NRR: Natural Recharge Rate of the Mancha Occidental aquifer (240 Mm? ). P1\&P2: Uniform volumetric and block-fate water prices when water demand is equal to the NRR of the aquifer.

Fig. 3. Water demand curves under uniform volumetric and block-rate water prices in the Mancha Occidental aquifer.
On the whole, Fig. 3 shows that movements along the demand curve result in significant water savings. However, a disaggregated analysis reveals that water demand responses are not uniform across farm types due to their diverse structural parameters (basically, crop distribution and farm size). Similar results have been obtained by Bazzani et al. (2005), Gómez-Limón and Riesgo (2004), and Varela-Ortega et al. (1998), among others. Fig. 4 shows the results of the application of uniform volumetric water prices on the selected farm types of the Mancha Occidental aquifer.

The simulation results indicate that water demand is less elastic at low prices in small and medium farms F1 and F2. In the medium farm F2, in particular, water demand is completely inelastic bellow $0.11 € / \mathrm{m}^{3}$, which means that water prices should be incremented 5 times before they will induce significant water savings. The inelasticity of water demand at low water price ranges may induce important farmers' income losses, limiting the applicability of water pricing schemes in real-world contexts (see e.g. Cornish et al., 2004; De Fraiture and Perry, 2007; Molle et al., 2008). At the same water price level $\left(0.11 € / \mathrm{m}^{3}\right)$, bigger farms F3 and F4 would save larger amounts of water, evidence of the presence of regional economies of scale. However, farm size is not the only fac-

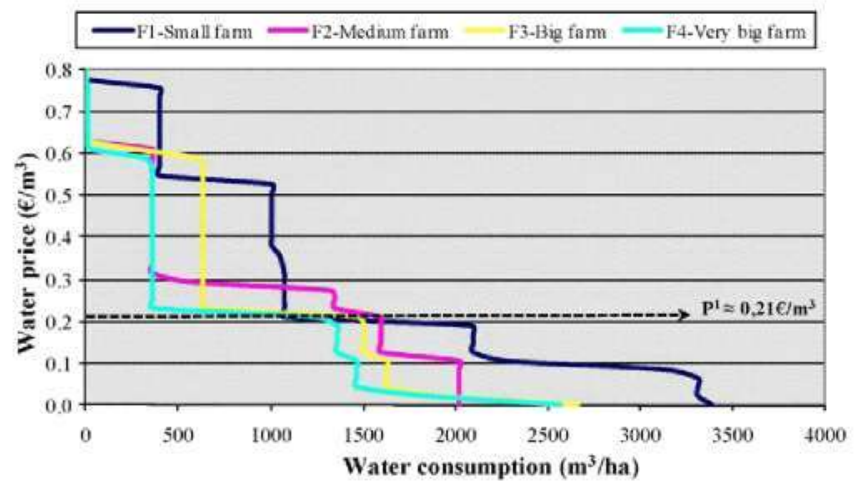

Fig. 4. Water demand curves under uniform volumetric water prices. 


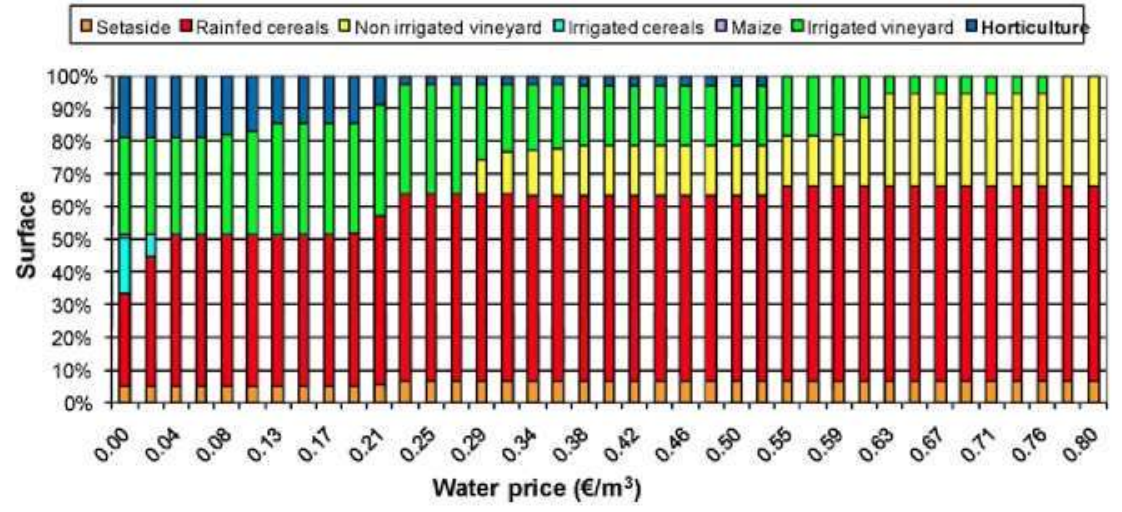

Fig. 5. Farmers' cropping strategies under uniform volumetric water prices.

tor that determines water demand responses. Water savings are clearly conditioned by potential land use changes. Crop diversified farms, such as F3 and F4, can adopt more flexible adaptive strategies and easily adjust their crop mix to decrease water consumption. These farm types combine rainfed and irrigated agricultural productions in different soil qualities and are capable of substituting irrigated cereal crops (such as barley, wheat, and maize) by rainfed crops (mainly, barley) for reducing water consumption without sacrificing a large part of their income. On the other hand, the representative farm F2 has a very rigid cropping pattern (based on irrigated vineyard crops) and therefore, it presents a very low price-responsive water demand. Similarly, the representative farm $\mathrm{F} 1$, with very low diversification potential and high value-added crops (such as vegetables and to a lesser extent, vineyards), substitutes water intensive crops (pepper) by less water demanding crops (melon or vineyard) at low prices, but it is constrained to replace vegetable crops with rainfed crops when water prices are high, reducing water consumption and farm income substantially. As evidenced by the data in Fig. 4, a water price level of $0.21 € / \mathrm{m}^{3}$, would induce a reduction in water consumption of $68,21,45$ and $52 \%$, in farms F1, F2, F3 and F4, respectively. Fig. 5 illustrates the cropping strategies adopted by farmers facing increasing uniform volumetric water prices in the Mancha Occidental aquifer.

The simulation results also indicate that the establishment of water prices as a mechanism to reduce groundwater consumption and assure the regeneration of the Mancha Occidental aquifer would have adverse effects on farmers' income in the region. Fig. 6 shows farmers' income under uniform volumetric and block-rate water prices.

Figs. 3 and 6 point out that, when uniform volumetric and block-rate water prices reach $0.21 € / \mathrm{m}^{3}$ and $0.11 € / \mathrm{m}^{3}$ respectively, farmers' would sacrifice $58 \%$ and $40 \%$ of their income gains

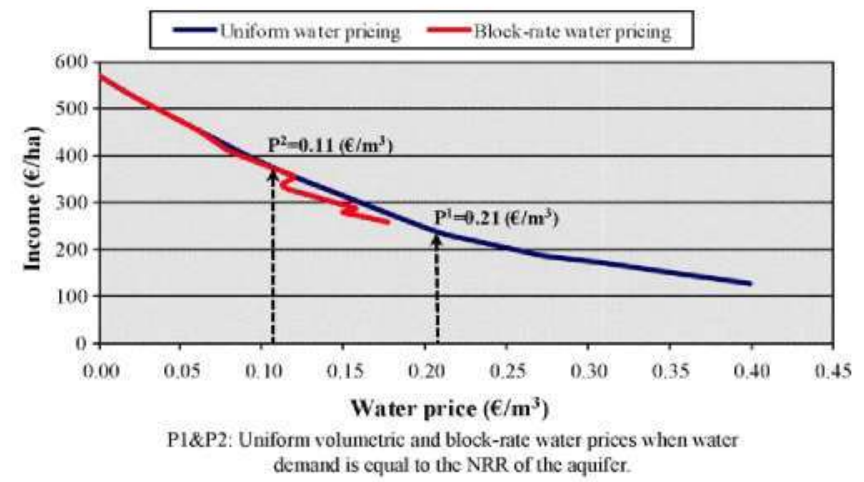

Fig. 6. Farmers' income under uniform volumetric and block-rate water prices in the Mancha Occidental aquifer. for reducing $50 \%$ their water consumption, which may be neither politically nor socially acceptable. Disaggregated results displayed in Table 5 show that, at that uniform water price level $\left(0.21 € / \mathrm{m}^{3}\right)$, the medium farm F2, specialized in growing irrigated vineyard, would even go out of farming (negative income). Irrigated vineyards as well as horticultural crops play a substantial role as a source of employment and income generation. Thus, alternative choices should be considered to reduce water use in vineyard intensive farms, because putting at risk the viability of these farms might severely curtail the economy of the region.

\subsubsection{Water quotas}

As an alternative to the prevailing WAP, a new water use quota system was devised to limit total groundwater abstractions for irrigation to $240 \mathrm{Mm}^{3}$ per year (water volume compatible with the Mancha Occidental aquifer's recharge rate). Unlike the current WAP, this global quota was equally distributed across types of farms in such a way that each farm was assigned a non-tradable groundwater use right of $1337 \mathrm{~m}^{3} / \mathrm{ha}^{8}$ The simulation results in Table 5 show that this water allotment reallocation would favor larger farms F3 and F4 more than small and medium farms F1 and F2. In comparison with the baseline scenario (see Table 5), big farms F3 and F4 would see their income gain reduced only by $10 \%$ and $5 \%$ respectively, whereas the smaller farms F1 and F2 would lose $27 \%$ and $61 \%$ of their income.

Regarding the public sector, it is worth mentioning that public collection would substantially increase in farms F1 and F2, especially in the latter $(299 € / \mathrm{h}$, in Table 5), as it comprises the legalization fees paid by irrigators for registering unlicensed wells to enter in the new water quota system. Besides that, public expenditure will slightly decrease in all farms due to expansion of rainfed crops in the cultivated area (rainfed crops received lower direct CAP subsidies than irrigated crops). Rainfed surface would increase from $5 \%, 3 \%, 20 \%$ and $50 \%$ (for farms F1, F2, F3 and F4, respectively, under the baseline scenario) to $54 \%, 26 \%, 21 \%$ and $80 \%$ under the quota system scenario.

\subsubsection{Water market}

In this section we take a further step, simulating a water market. The water market simulated in this study can be defined as an irrigation spot market implemented at sub-basin level. Thus, groundwater can be voluntarily and directly traded among irrigators within the Mancha Occidental aquifer, but it cannot be transferred to other irrigation systems outside the aquifer's

\footnotetext{
8 These individual water quotas were obtained by dividing the global water quota $\left(240 \mathrm{Mm}^{3}\right.$ ) by the total number of irrigation hectares in the area (on the order of 180,000 ha).
} 
boundaries, nor exchanged with water users belonging to other production sectors (e.g. residential and commercial sectors). In order to guarantee the aquifer's annual recharge rate, total water exchanges are limited to a maximum of $240 \mathrm{Mm}^{3}$ per year. The initial allocation of groundwater rights for each farm corresponds with the established water use quotas of the previous simulation scenario (1337 $\mathrm{m}^{3} / \mathrm{ha}$, that is, $75,73,42$ and $50 \mathrm{Mm}^{3}$ for $\mathrm{F} 1, \mathrm{~F} 2, \mathrm{~F} 3$ and $\mathrm{F} 4$ respectively), in such a way that the sum of initial water rights equals the maximum exchangeable amount of water in the Mancha Occidental aquifer. Simulation results from the previous water use quota scenario have also been used to define the range of potential water market prices that provide a win-win situation (from 0.20 to $0.26 € / \mathrm{m}^{3}$ ). These price levels were identified within the range of prices delimited by the lowest and highest dual water values of the water availability restrictions in the simulated water use quota scenario. Among the possible market prices, the equilibrium market price was set at $0.24=/ \mathrm{m}^{3}$; the level at which the expected regional utility is maximized. Since even the most efficient water market entails establishment and operation costs, it has been considered that water sellers have to pay for the transaction costs incurred in the trading (around 5\% of the total receipts).

Results indicate that the medium farm F2 buys $0.8 \mathrm{Mm}^{3}$ from the largest farm F4, because of the higher marginal utility or opportunity cost of water of small and medium holdings. Once the transaction has been completed, total water consumption is $74.6 \mathrm{Mm}^{3}\left(1351 \mathrm{~m}^{3} / \mathrm{ha}\right)$ for farm $\mathrm{F} 2$ and $50.5 \mathrm{Mm}^{3}$ $\left(1315 \mathrm{~m}^{3} / \mathrm{ha}\right.$ ) for farm F4 (see Table 5). Gómez-Limon et al. (2007) demonstrate that, for most market price levels, farmers' willingness to buy water is higher in small and medium farms than in large farms. In comparison with the previous non-market situation (water use quota scenario), water trading results in small income gains (farm income is only increased in 1є/ha in farms F2 and F4), and slightly higher public collections ( 303 and $4.5 €$ /ha in farms F2 and F4 respectively).

\subsection{Cost-effectiveness analysis of water management policies}

To conclude our research, a CEA analysis was performed to identify the most cost-effective policy option to meet the WFD objective of water resources conservation in the Mancha Occidental aquifer. According to theory in environmental-economic evaluation, the purpose of the CEA is to find out how preset environmental objectives (in our case, reducing total groundwater consumption for irrigation in the aquifer to reach its sustainable recharge rate, set at $240 \mathrm{Mm}^{3}$ ) can be attained at least social cost. Following Brouwer and De Blois (2008), Semaan et al. (2007), Turner et al. (2004), and Zanou et al. (2003), this analysis was developed comparing the net social cost of the different simulated water management policies with respect to the baseline situation. The most-effective water management policy will be that with the lowest net social cost.

Net social costs are calculated as the algebraic sum of private and social costs related to each policy measure (Mejías et al., 2004; Semaan et al., 2007; Varela-Ortega and Blanco, 2008; Varela-Ortega and Sumpsi, 1999). Private costs refer to farmers' income losses and public costs express the government net public expenditure (see Section 4.1). Table 6 shows the private and public costs of each water management policy (with respect to the baseline situation) in the Mancha Occidental aquifer.

Results leads to the conclusion that the most cost-effective water management policy would be the establishment of a water pricing system, ranked \#1 with the lowest net social cost $(85.3 \epsilon /$ ha). Table 6 shows that uniform volumetric and blockrate water pricing schemes have the lowest public costs $(-314.5$ and $-210.5 €$ /ha respectively), but entail the highest private costs ( 399.8 and $295.8 €$ /ha respectively). On the other hand, the water use quota system is the most costly water management policy and it is ranked \#3. This water management policy has the highest net social cost $(86.9 € / \mathrm{ha})$, and presents the highest public cost $(-89.8 \in$ /ha $)$. In between, the water market policy instrument is ranked \#2. It has a net social cost of $85.8 \in$ ha, but entails the lowest private cost $(176.5 \mathrm{e} / \mathrm{ha})$. It is worth mentioning that public costs are negative in all cases (government collections are higher than government expenditures because of the taxes collected by legalizing the unlicensed wells), so public costs should be understood as public revenues in Table 6.

\section{Discussion of the results}

The results show that attaining the target of the aquifer's sustainability would require an effective simultaneous combination of measures addressed to control water consumption and halting illegal drilling.

Closing up unlicensed wells would reach the environmental objective of the aquifer's conservation, but it would be opposed by small and medium-size farmers who will undergo acute income losses. Taking into consideration that the current WAP is highly contested by the farmers and that the water Administration has not been capable of enforcing this policy due to the large costs incurred in monitoring and metering water consumption, it seems unlikely that 20,000 wells (almost the $50 \%$ of the wells in the Mancha Occidental aquifer) can be closed. Kemper (2007) and Koundouri (2004) warn about the high transaction costs of monitoring individual wells, and Molle et al. (2008) inform about the risk of farmers' uprisings when imposing extremely costly fines on unlicensed wells. In addition, historical evidence shows that any attempts to prosecute illegal pumping in the study area ended up in numerous lawsuits, still pending to be settled by the Spanish court (CHG, 2007; Llamas and Martinez-Santos, 2005). On the other hand, the results show that the taxed legalization of unlicensed wells would entail milder income losses to farmers and lower enforcement costs to the public authorities than the closing-up scenario. ln Jordan, a similar experiment also proved effective with the legalization in 2005 of numerous unlicensed wells. Irrigators were given the opportunity to obtain an abstraction license for free, but were encouraged to change the legal status of their wells by paying higher tariffs for the water abstracted from unlicensed wells (Haddadin, 2006). The taxed legalization of unlicensed wells can control illegal groundwater pumping, but it is not sufficient to recovery the aquifer. Rather, effective water management in this area will require the implementation of other water management policies as well.

The establishment of water pricing policies can reduce groundwater consumption and promote the recovery of the aquifer. The results show that water tariffs would induce substantial water savings, especially in large crop-diversified farms. Recent studjes on water prices (e.g., Schoengold et al., 2006; Wheeler et al., 2008) suggest that irrigation water demand is more elastic than highlighted in other studies (e.g., Cornish et al., 2004; De Fraiture and Perry, 2007; Varela-Ortega et al., 1998) and that water prices can encourage water savings even at low rates. Shiferaw et al. (2008) demonstrate that well-defined and implemented groundwater prices in lndia would induce changes in land allocation and the implementation of water saving technologies, inflicting moderate income losses upon the farmers. Our findings indicate that groundwater prices promote water saving, but they inflict substantial income losses upon small farms with rigid cropping patterns. A comparative policy analysis between the two selected water pricing schemes leads to the conclusion that block-rate water prices would provide fewer revenue collections to the water authority. 
Table 6

Costs and effectiveness of water management policies in the Mancha Occidental aquiter.

\begin{tabular}{|c|c|c|c|c|c|}
\hline \multirow[t]{2}{*}{ Index } & & \multicolumn{4}{|l|}{ Water management policy } \\
\hline & & Uniform w. p. $\left(P=0.21=/ \mathrm{m}^{3}\right)$ & Block-rate w. p. $\left(P=0.11 \in / \mathrm{m}^{3}\right)$ & Water use quotas & $\begin{array}{l}\text { Water market } \\
\left(P=0.24=\left(\mathrm{m}^{3}\right)\right.\end{array}$ \\
\hline \multirow[t]{2}{*}{ Private cost } & eflia & 399.8 & 295.8 & 176.6 & 176.5 \\
\hline & $q^{3}$ & -63 & -47 & -28 & -28 \\
\hline \multirow[t]{2}{*}{ Public cost } & etha & -314.5 & -210.5 & -89.8 & -90.7 \\
\hline & $\mathrm{s}^{\mathrm{d}}$ & +244 & +163 & +69 & +70 \\
\hline Net social cost (e/ha) & & 85.3 & 85.3 & 86.9 & 85.8 \\
\hline Ranked cost-effect iveness ${ }^{b}$ & & & & 3 & 2 \\
\hline
\end{tabular}

- Percentage of private and public cost wit li respect to the baseline scenario.

b Simulated management instruments have been ranked from 1 to 3, having the \# 1 the highest cost-effectiveness.

but would mean lower income losses for farmers. Several authors (such as Bar-Shira et al., 2006; Dinar and Subramanian, 1997; Liu et al., 2003; Olmstead et al., 2007), highlight the benefits of using block-rate water pricing systems for combining efficiency and equity considerations and indicate that block-rate pricing, although usually applied to the urban water sector, is being progressively introduced to regulate agriculture water uses.

Equally distributed water quotas can also achieve the environmental objective of the aquifer's conservation by reducing groundwater consumption and inequity among farmers. Molle (2009) and Wichelns (1999) state that quantity-based restrictions may induce land use changes in the same way as explicit water prices do. In addition, Shiferaw et al. (2008) demonstrate that the use of water quotas increase the feeling of equity among farmers and encourage groundwater users to cooperate and to act in the interest of the collective.

The results obtained indicate that, when the previously established water use quotas are traded on a market-based mechanism, only small amounts of water are actually exchanged, providing small income gains. Shiferaw et al. (2008) also prove that groundwater markets in semi-arid areas are usually not completely developed as a consequence of the low profits obtained. Along the same lines lines, Gómez-Limon et al. (2007) and Zekri and Easter (2005) state that intra-sectoral water markets for irrigation result in small water trades and minor increases in farmers' income, proving fewer benefits than the mainstream neo-classical economic theory would advocate for market mechanisms. In the present study, a win-win trading situation will occur when market prices vary from 0.20 to $0.26 \epsilon / \mathrm{m}^{3}$. These results match with other studies on hypothetical water markets in irrigation districts of southern Spain (see for instance Arriaza et al., 2002; Calatrava and Garrido, 2005), which document equilibrium prices as being around $0.15-0.30 € / \mathrm{m}^{3}$ (for 1000 and $2000 \mathrm{~m}^{3}$ /ha of water allotments respectively, in years of normal supply). Albiac et al. (2006) also analyze real informal water markets for irrigation in a South-eastern basin of Spain, and report exchange prices in the range of $0.1-0.4=/ \mathrm{m}^{3}$.

The cost-effective analysis concludes that any of the water management instruments considered in this research has a clear advantage, in terms of social costs, over the others. Similarly, Dinar et al. (1997) state that no single economic instrument can work in all situations. Alauddin and Quiggin (2008) also confirm that no single policy can solve the complex problems related to irrigation water management, and recommend a combination of market and non-market measures. However, the differences obtained in the present study between private and public costs at farm and at sub-basin level will be decisive for putting water conservation policies into practice since they may condition the acceptance and involvement of the end-users in the policies' enforcement. Accordingly, Zanou et al. (2003) emphasizes that encouraging the cooperation and co-ordination among the stakeholders will be the least costly way to improve watershed quality in a river basin.

\section{Conclusions and policy implications}

Complying with WFD principles presents a significant challenge for most European basins in terms of management and methodology. Particularly, fulfilling the 'polluter pay' principle and the cost recovery objective requires the development of novel methodologies to evaluate their potential impacts and costs. Some studies and guidance documents exist, but they need to be further elaborated to incorporate water quantity issues, different spatial scales and transferable empirical experiences. The methodology developed in this paper attempted to shed light on these questions, analyzing the cost and effectiveness of different water conservation policies to reduce groundwater consumption and assure the sustainability of the Mancha Occidental aquifer.

In agreement with other authors (Bazzani et al., 2005; Gómez-Limón and Riesgo, 2004; Medellín-Azuara et al., 2010; Varela-Ortega et al., 1998), our results confirm that the application of water management policies would produce differential effects across farm types. Most of the studies about CEA are exclusively specified at river basin level, missing important differences at local scale (in terms of soil, agrarian structure, farmers' behavior, technological conditions, and site-specific institutional factors) as well as important interactions among the different levels of analysis. Our findings demonstrate that a multi-scale modeling approach is more realistic and highly recommended.

The study also shows that various alternative mechanisms can be used to attain the target of the aquifer's sustainability. Results indicate that the best policy option for establishing an efficient regulatory framework to control unlicensed drilling is the taxed legalization of unlicensed wells. However, this policy option will not be capable of dealing on its own with groundwater overdrafts and it will be necessary to apply other water conservation policies to attain the aquifer's sustainability target. From this study we can infer that none of the considered alternative water conservation policies (water pricing, water quota, water market) is clearly more cost-effective than the others.

Aggregate results show that net social costs are not substantially different across policy options. However, there are important differences between private and public costs (at farm and subbasin level), which may influence the political viability of the various options. From an overall perspective, uniform volumetric and block-rate water pricing policies are the most cost-effective instruments to reach the goal of aquifer's sustainability. However, both pricing schemes (especially, uniform volumetric water prices) will entail important income losses to medium farms with more rigid cropping patterns (such as vineyards) and could therefore put their viability at risk. The quota system inflicts lower income losses upon the farmers, but is the most costly option for the government and the least cost-effective instrument to recover the aquifer. The water market has the lowest private cost, but does not provide as much profit gains as the mainstream neo-classical economic theory would suggest. Thus, our results confirm the findings of Dinar 
et al. (1997), and Alauddin and Quiggin (2008) among others, who state that no single policy can solve the complex problems related to irrigation water management, and recommend a combination of market and non-market measures.

Additional studies on net social costs are highly recommended to include long term recurrent costs, as well as policy implementation and operation costs. Other criteria not considered in this research, such as the policy enforcement capacity and level of social acceptance, should also be taken into consideration. Experiences from the past indicate that water quotas are likely opposed by the farmers and entail high costs of monitoring and enforcement. Increasing the direct participation and involvement of stakeholders in water management decisions is highly necessary for the acceptance of the policies. Notwithstanding the research's limitations, we would like to stress the potential of this methodology for environmental-economic modeling and policy analysis. Even though no clear cost-effective solutions were found, this methodology improves the ability to predict policy impact at multiple scales and provide valuable results for the stakeholders with regards to the potential impacts and costs of the WFD in a wide variety of contexts and water policy scenarios.

\section{Acknowledgments}

This paper is part of the first author's PhD thesis (BlancoGutierrez, 2010), carried out with scholarships of the Spanish Ministry of Education (AP2007-00433), the Universidad Politécnica de Madrid, and the Center for the study of risk management in agriculture and natural resources. The methodology used in this study was developed at the Mediterranean Agronomic Institute of Montpellier (IAMM-CIHEAM) during a postgraduate research period in 2007. The authors would like to acknowledge the EU projects NEWATER (New Approaches to Adaptive Water Management under Uncertainty. $\Omega^{\circ}$ : FP6-2003-GLOBAL2-SUSTDEV-6.3.2-511179-2) (2005-2009), and SCENES (Water Scenarios for Europe and for Neighbouring States, $n^{\circ}$ FP62005-GLOBAL-4-OJ 2005 C 177/15) (2007-2011) for providing complementary research funds for this study.

\section{Appendix A. Specification of the economic model}

This appendix presents the essential elements of the economic model described in the text. While this model was developed for application to the Upper Guadiana basin, it was designed to be easily adaptable to a variety of situations.

\section{A.1. Objective function}

Based on the mean-standard deviation analysis, the objective function of the model is:

$\operatorname{Max} U=\sum_{f}\left(Z_{f}-\phi \cdot \sigma_{f}\right)$

where $U$ is the regional expected utility; $Z_{f}$ the average net income by farm type $(f) ; \phi$ the risk aversion coefificient; $\sigma_{f}$ the standard deviation of the income distribution by farm type (f). Average farm income is calculated as follows:

$$
\begin{aligned}
& Z_{f}=\sum_{c} \sum_{k} \sum_{r} \sum_{i} g m_{c, k, r}+X_{c, k, r, i, f}+s f p_{f} \cdot m d \cdot n t m f_{f}-o c \\
& \cdot \sum_{p} f a_{p f^{\prime}}-h l p \cdot \sum_{p} h l_{p j}-\sum_{i} n v i n_{i, f}+i n v c-\sum_{i} \operatorname{vin}_{i, f} \cdot p t i l c \\
& -\sum_{i} w p \varepsilon_{i, j}-\sum_{i} \operatorname{sing} g_{i, f} \cdot w \operatorname{tarif} f_{i}-\sum_{i} w e l l_{i, j} \cdot w_{e} \mathrm{ll}_{i}
\end{aligned}
$$

where $X_{c, k, r, j, f}$ are the decision-making variables representing the growing area by crop type $(c)$, soil type $(k)$, irrigation technique $(r)$, legal status of the water used (i), and farm type $(f) ; g m_{c, k . r}$ gross margin (including the coupled subsidies of the Common Agricultural Policy (CAP)): $s f p_{f}$ single farm payment (decoupled subsidies of the (AP); md modulation rate; numf number of farms; oc family labor opportunity cost; $f l a_{p f}$ family labor; hip wage for hired labor; $h l_{p j}$ hired labor; nvin ${ }_{i f}$ new vineyard surface; invc annual payment of the investment costs incurred in planting new vineyards; vin $_{i, f}$ surface of vineyard pulled up; pullc annual payment of the costs incurred in pulling up vineyards; wpc $c_{i, f}$ water pumping costs; sirrg $g_{i, f}$ irrigated surface; wtarif $f_{f}$ water use tariff; well iff $_{\text {num- }}$ ber of wells; wellt tax paid by well (not applicable to unlicensed wells).

The standard deviation is generated by a set of states of nature defined by climate variability (crop yields) and market variability (crop prices) as follows:

$\sigma_{f}=\left[\frac{\left(\sum_{s n} \sum_{s m} Z_{s n, s m, f}-Z_{f}\right)^{2}}{N}\right]^{1 / 2}$

where $Z_{\text {sinsm } f}$ is the random income; $N$ the combination of the different states of nature $(N=100)$.

\section{A.2. Constraints}

- Land constraints:

- Availability of land resources. Eq. (4) indicates that the cultivated area cannot surpass the potential arable land $\left(\right.$ surf $\left._{k, f}\right)$. Eq. (5) limits the area under irrigation to the total area of potentially irrigable land $\left(\right.$ sirrg $\left._{i, f}\right)$.

$$
\begin{aligned}
& \sum_{i} \sum_{r} \sum_{i} X_{i, k, r, i f f} \leq s u r f_{k, j} \\
& \sum_{i} \sum_{k} \sum_{\pi} X_{i, k, r i, j} \leq \operatorname{sing}_{i, j}
\end{aligned}
$$

- Vineyard land acquisitions. Eq. (6) states that the cultivated vineyard surface is determined by the current 'plantation rights' ( svin $\left._{i, f}\right)$, surface of vineyard pulled up ( in $_{i, f}$ ) and the new vineyard plantations ( $n$ vin $n_{i, f}$ ). According to the vineyard restructuring programs in Castilla-La Mancha, as part of the CAP, vine growers are allowed to create new vineyard plantations (up to max nvin). This is a single-period MPM, so we assume that vineyards are in full production.

$\sum_{i, i} \sum_{k} \sum_{r} X_{i j, k, r, i, f}=s \sin _{i, f}+n v i n_{i, f}+1 i n_{i, f} ;$

where $\sum_{i} \sum_{f} v i_{i f f} \leq \max n v i n$

- Labor constraints. Eq. (7) indicates that the seasonal labor requirements must to be covered by total available agricultural labor (family, lafa $a_{p,}$, and hired labor, $/ h i_{p, f}$ ).

$\sum_{c} \sum_{k} \sum_{r} \sum_{i} l r_{c, r, p} \cdot X_{c, k, r, i, f} \leq l a j a_{p, f}+h i_{p, f}$

- Water constraints (and some other relevant hydrology equations): 
- Water availability at the farm level. Eq. (8) illustrates that the crop water needs $\left(w_{c k, r}\right)$ cannot exceed the amount of water available at the farm level ( watera $)_{f}$.

$$
\sum_{c} \sum_{k} \sum_{r} \sum_{i} w r_{c, k, r} \cdot X_{c, k, r, i, f} \leq \text { watera }_{i, f}
$$

- Water availability at the sub-basin level. Eq. (9) limits the total water consumption in the aquifer $\left(w c_{j, f}\right)$ to the amount of water available at the sub-basin level $\left(t w c_{i}\right)$ (usually subjected to the Natural Recharge Rate of the Mancha Occidental aquifer).

$\sum_{f} w c_{i, f} \leq t w c_{i}$

- Estimation of water pumping costs. Eq. (10) shows how pumping costs increase as water levels in the aquifer decline. In the present study, water consumption was used as a proxy for measuring changes in groundwater levels. $\sigma_{j}, \beta_{i+} \delta_{j}$, are the coefficients of the polynomial function of groundwater pumping costs, obtained using statistical analysis from experimental field data collection.

$\alpha_{i} \cdot\left(w c_{i, f}\right)^{2}+\beta_{i} \cdot w c_{i, f}+\delta_{i}=w p c_{i, f}$

- Policy constraints. Eq. (11) depicts the EU CAP requirement for farmers to set-aside a $\left(X_{s a, k, r, f, j}\right)$ a given fraction (bound by a minimum, smin, and a maximum, smax) of the COP (cereals, oilseeds and proteins) growing area $\left(X_{\text {cop r, }, d, f}\right)$.

$$
\begin{aligned}
& s \min \cdot \sum_{i \circ p} \sum_{k} \sum_{r} \sum_{i} X_{c \omega, \text {, k.r.i.j }} \leq \sum_{k} \sum_{\mathrm{r}} \sum_{i} X_{\text {sa.k.r.i.j }} \leq s \max \\
& \sum_{i o p} \sum_{k} \sum_{\tau} \sum_{i} X_{c \omega, k, r, i, j}
\end{aligned}
$$

- Subsequently, other parameters and constraints are added into the model for simulating different water policies (e.g. legalization fees, administered water prices, water market prices, transaction costs, water trading, etc.).

\section{References}

Alary, V., Deybe, D., 2005. Impacts of different water tariff tetorms on cural livelihood and water and public resource in India: The case of Haryana producers Internat ional Journal of Water 3, 84-99.

Alauddin, M., Quiggin, J., 2008. Agricultural intensification, icrigation and the environment in South Asia: Issues and policy options. Ecological Economics 65, 111-124.

Albiac, J., Hanemann, M., Calatrava, J., Uche, J., Tapia, J., 2006. The rise and fall of the Ebro water transfer. Natural Resources Journal 46, 727-758.

Artiaza, M., Gómez-Limón, J.A., Upton, M., 2002, Local water markets tor irtigation in sout hern Spain: A multicriteria approach. The Aust ralian Journal of Agricultural Resource Economics 46, 21-43.

Bar-Shira, Z., Finkelshtain, l., Simhon, A., 2006. Block-rate versus uniform water pricing in agriculture: An empirical analysis. American Journal of Agricultural Economics 88, 986-999.

Bazzani, G.M., Di Pasquale, S., Gallerani, V., Morgantì, S., Raggi, M., Viaggi, D., 2005. The sustainability of irrigated agricultural systems under the Water Framewotk Directive: First results. Environmental modelling and Software 20, 165-175.

Bjornlund, H., Nicol, L., Klein, KK., 2007. Challenges in implementing economic instcuments to manage irtigation water on tarms in southern Albetta, Agricultural Water Management 92, 131-141.

Blanco-Gutiêrrez, I., 2010. Economic-hydrologic analys is of water management strategies for balancing water tor nature and water for food. Implicat ions for the Guadiana River Basin, in Spain. PhD Thesis. Universidad Politécnica de Madrid. Madrid, Spain, $287 \mathrm{pp}$.

Brouwer, R., De Blois, C., 2008 . Integrated modelling of risk and uncertainty underlying the cost and effectiveness of water quality measures. Environmental Modelling \& Soltwate 23, 922-937.

Buckwell, A.E., Hazell, P.B., 1972. Implications of aggregation bias for the construction of static and dynamic linear programming supply models. Journal of Agricultural Economics 23, $119-134$.
Calatrava, J., Gartido, A., 2005. Modelling water matkets under uncertain water supply. European Review of Agricultural Economics 32, 119-142.

CHG (Contederación Hid rográfica del Guadiana), 2006, Régimen de explotación para el año 2007 de la Unidad Hidrogeolóngica de la Mancla Occidental y de un perímetro adicional de la Unidad Hidrogeológica de la sierra de Altomira, Ciudad Real, Spain.

CHG (Confederación Hidrográfica del Gilladiana), 2007. Plan Especial del Alto Giuadiana, Ciudad Real, Spaiı.

Chohin-kupet, $A_{*}$, Rieu, T, Montginoul, M., 2003. Water policy reforms: Pricing water, cost recovery, water demand and impact on agriculture. Lessons from the Mediterraneall experience. Paper presented at the Water Pricing Seminar, Parallel session $C$ : on the impact of cost recovery on agriculture, Agencia Catalana del Agua \& World Bank Institute, Barcelona, Spain, June 30- July 2, 2003.

Cormish, G., Boswortlı, B., Perty, C.]., Burke, J.J., 2004. Water cliatging in irrigated agriculture: An analysis of international experience. In: FAO Water Reports No. 28. FAO, Rome, It aly.

Day, R.H., 1963. On aggregating linear programming models of production. Journal of Farm Economics 45, 797-813.

De Fraiture, C., Perry, C.J., 2007. Why is agricultural water demand umesponsive at low price ranges? In: Molle, F., Berkoff, J. (Eds.), Irrigation water pricing: The gap between theory and practice, Comprehensive Assessment of Water Management in Agriculture. IWMIFCABI, Wallingford, UK and Cambridge, MA. USA. pp. 94-107.

Dimat, A., Rosegrant, M.W., Meinzen-Dick, R., 1997. Water allocation mechanisms. Principles and examples. In: World Bank Policy Research Working Paper No. 1776. World Bank, Washington, DC, USA.

Dinar, A., Subramanian, A., 1997. Water pricing experiences: An international perspective. In: World Bank Technical Paper No. 386. World Bank, Washington DC, USA.

Easter, K.W., Rosegrant, M.W., Dinar, A., 1998. Markets for water: Potential and performance. Kluwer Academic Publishers, New York, USA.

EC(Eucopean Communities). 2000. Directive 2000/60/EC of the Eu ropean Patliament and of the Council of 23 October 2000 establishing a framework for Community action in the field of water policy. Otticial journal of the European Communities L327. Office for official Publications of the European Communities, Luxembourg.

Ellis, F., 1993, Peasant economics: Farm households and agrariandevelopment. Cambridge University Press, Cambridge, UK.

Feinerman, E., 1988. Groundwater management: Efficiency and equity considerations. Agricultural Economics 2, 1-18.

Flichman, G., Donatelli, M., Louhichi, K., Romstad, E., Heckelei, T., Auclair, D., Garvey, E., Van Ittersum, M., Janssen, S. Elbersen, B., 2006. Quantitative models of SEAMLESS-IF and procedures tor up- and downiscalim. SEAMLESS Report No. 17. SEAMLESS Integrated Project EU Sixth Framework Programme Cont ract No. 010036-2, $112 \mathrm{pp}$.

Foster, S.S., Chilton. P.J., 2003. Giroundwater: The processes and global signific ance of aquiter degradation. Philosophical Transactions of the Royal Society of London Series B: Biological Sciences 358, 1957-1972.

Friedman, M., Savage, L.P., 1948. The utility analysis of choices involving risk. Journal of Political Economy 56, 279-304.

Carrido, A. Calatrava, J, 2010. Recent and future trends in water charging and water markets. In: Garrido, A., Llamas, M.R. (Eds.), Water Policy in Spain. Taylor \& Francis Group, London, UK.

Garrido, A., Martínez-Santos, P., Llamas, M.R., 2006. Groundwater irrigation and its implications for water policy in semiarid count ries: The Spanish experience. Hydrogeology Journal 14, 340-349.

Giordano, M., Villholth, K.G., 2007. The agricultural groundwater revolution: Opportunities and threats to development. In: Molden. D. (Ed.), Compreliensive Assessment of Water Management in Agriculture Series. IWMI/CABI, Wallingford, UK and Cambridge, MA, USA.

Gómez-Limon, J.A., Bebel, J., Arríaza. M. 2007. MCDM Farm System Analysis for Public Management of Irrigated Agriculture. In: Weint raub, A., Romero, C., Bjørndal, T., Epstein, R., Miranda, J. (Eds.), Handbook on operation researcli in natural resources. Springer US, Boston, MA, pp. 93-114.

Gómez-Limón, J.A., Riesgo, L., 2004. Itrigation water pricing: Differential impacts on irrigated farms. Agricultural Economics 31, 47-66.

Gordon, H.S., 1954. The economic theory of a common property resource: The fishery. Joutinal of Political Economy 62, 124-142.

Haddadin, M.J., 2006. Water resources in Jordan. Evolving policies for development the enviromment and conflict resolution. Resoutces for the Future Press, Wasliington, DC, ISA.

Hardaker, J.B., Huirne, R.B.M., Anderson, J.R., Lien, G., 2004. Coping with risk in agriculture, second edition. CABI Publishing.

Hardin, G., 1968. The tragedy of the commons. Science 162, 1243-1248.

Hazell, P.B., Norton, R.D. 1986. Mathematical programming tor economic analysis in agriculture. Macmillan Publishing Company, New York, USA, 400 pD.

Henseler, M., Wirsig. A. Herrmann, S., Krimly. T., Dabbert, S., 2009. Modeling the impact of global change on regional agricultural land use througl an activity-based non-linear programming approach. Agricultural Systems 100 . $31-42$.

Huitne, R.B.M., Meuwissen, M., Hatdaket, J.B., Anderson, J.R., 2000. Risk and risk management in agriculture: An overview and empirical results. International Jounal of Risk Assessment and Management 1, 125-136.

IES (Instituto de Estadistica de Castilla La Mancha), 2006. Estadisticas estructurales, Junta De Comunidades De Castilla-La Mancha, Toledo, Spain.

Iglesias, E, 2002. La gestión de las aguas subterráneas en el acuíteco Mancha Occidental. Economía Agraria Y Recursos Naturales 2, 69-88. 
lglesias, E., Blanco, M., 2008. New directions in water resoutces management: The role of water pricing policies. Water Resources Research 44, 1-11

Interwies, E., Borchardt, D., Kraemer, R.A., Kranz, N., Götlach, B., Richter, S., Willecke, J., Dworak, T, 2004. Basic principles for selecting the most cost-effective combinations of measures for inclusion in the programme of measures as desc ribed in Atticle 11 of the Water Framework Directive. Ecologic Institute of Water Resources Research, University of Kassel, Berlin, Germany.

Johansson, R.C., Tsur, Y., Roe, T.L., Doukkali, R., Dinar, A., 2002. Pricing ìrigation water: A review of theory and practice. Water Policy 4, 173-199.

Kemper, K.E., 2001. Markets for tradable water rights. In: Meinzen-Dick, R.S., Rosegrant, M.W. (Eds.), Overcoming Water Scarcity and Quality Constraints. A 2020 vivison for food, agriculture, and environment, Focus 9. International Food Policy Research Institute, Washington DC, USA.

Kempet; K.E., 2007. Instruments and institutions tor groundwater management. In: Giordano, M. (Ed.). Agricultural groundwater revolution: Opportunities and thiteats to development. IWMIJCABI, Wallingtord, UK and Cambridge, MA, USA, pp. 153-172.

Koundouri, P., 2004. Current issues in the economics of groundwater resource management. Journal of Economic Sutveys 18, 703-740.

Liu, J., Savenije, H.H., Xu, J., 2003. Water as an economic good and water tariff design Comparison between IBT-con and IRT-cap. Physics and Chemistry of the Earth $28,209-217$

Llamas, M.R., Martínez-Santos, P., 2005. Intensive groundwater use: Silent revolution and potential soutce of social conflicts, Jou rnal of Water Resou rces Planning and Management 131, 337-341.

Martímez-Santos, P., Hentiksen, H.J., Zotrilla, P., Martímez Altato, P.E., 2010. Comparative reflections on the use of modelling tools in conflictive water management settings: The Mancha Occidental aquifer, Spain. Environmental Modelling \& Software 25 (11), 1439-1449.

Martínez-Santos, P., Llamas, M.R., Martínez-Alfaro, P.E., 2008. Vulnerability assessment of groundwater resources: A modelling-based approach to the Mancha Occidental aquiter, Spain, Enviconmental Modelling \& Soltwate 23, 1145-1162.

Maton, L., Leenhardt, M., Bergez, J., Goulard, M., 2005. Assessing the irrigation strategies over a wide geographical area from structural data about farming systems. Agricultural Systems 86, 293-311.

Medellím-Azuara, J., Harou, J.J., Howitt, R.E., 2010. Estimat ing econom ic value of agricultural water under changing condit ions and the effects of spatial aggregation. Science of the Total Environment 408, 5639-5648.

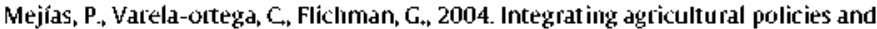
water policies under water supply and climate uncertainty. Water Resources Research 40, W07S03.

Millimam, J.W., 1956. Commonality, the price system and use of water supplies. The Southern Journal 22, 426-437.

MMA (Ministeriode Medio Ambiente), 2007. Precio y costes de los servicios del agua en España. Informe integrado de recuperación de costes de los servicios de agua ell España, Attículo 5 y Anejo III de la Directiva Marco del Agua, Madrid, Spail.

Molle, $F_{*}$ 2009. Water scarcity, prices and quotas: A review of evidence on icrigation volumet ric pricing. Irrigation and Drainage Systems $23,43-58$.

Molle, F., Berkoft, J., 2007. Water pricing in irrigation: Mapping the debate in the light of experience. In: Molle, F., Berkoff, J. (Eds.), Irrigation water pricing: The gap between theory and practice, Comprehensive Assessment of Water Management in Agriculture. IWMIfCABI, Wallingtord, UK and Cambridge, MA, USA, pp. $21-93$.

Molle, F., Venot, J. Hassan, Y., 2008, Itrigation in the Jordan Valley: Are water pricing policies overly optimistic? Agricultural Water Management 95, 427-438.

Olmstead, S.M., Hanemann, W.M., Stavins, R., 2007. Water demand under alternative price structures. Journal of Environmental Economics and Management 54, 181-198.

Olson, M., 1965. The Logic of Collective Action: Public goods and the theoryot groups. Harvard University Press, Cambridge, MA.

Postle, M., Foottit, A., Fenn. T., Salado, R., 2004. CEA and developing a methodology for assessing disp coportionate costs. Final Repott for Defta, WAG, SE and DOENI. Risk \& Policy Analysists Limited, London, UK.

Poussin, J.C., Imache, $A_{*}$ Le Grusse, $P_{*}$ Beji, R, Benmiloub, A., 2008, Exploting regional irrigation water demand using typologies of farms and production units: An example from Tunisia. Agricultural Water Management 95, 973-983.

Rogrers, P. De Silva, R., Bhatia, R, 2002. Water is all economic good: How to use prices to promote equity, efficiency, and sustainability. Water Policy 4, 1-17.

Rosegrant, M.W., Schleyer, R,G. 1996. Establishing tradable water rights: Implementation of the Mexican water law. Irrigation and Drainage Systems 10, 263-279.

Rounsevell, M.D., Annetts, J.E., Audsley, E., Mayr, T., Reginster, I., 2003. Modelling the spatial distribution of agricultural land use at the regional scale. Agriculture, Ecosystems \& Environment 95, 465-479.
Schlager, E., López-Gunm, E., 2006, Collective systems for water management: Is the Tragedy of the Commons a myth? In: Rogers, P.P., Llamas, M.R., MartinezCottina, L (Eds.), Water crisis: Myth or teality? Taylor and Francis, London, UK pp. 44-58.

Schoengold, K., Sunding, D.L., Moreno, G., 2006. Price elasticity reconsidered: Panel estimation of an agricultural water demand function. Water Resources Researcl $42,9411$.

Schuyt, K., 2005. Economic consequences of wetland degradation for local populations in Africa. Ecological Economics 53, 177-190.

Semaan, J., Flic hman, G., Scardigno, A., Steduto, P., 2007. Analysis of nitrate pollution contenol policies in the irrigated agriculture of Apulia Region (Southern Italy): A bio-economic modelling approach. Agricultural Systems 94, 357-367.

Shah, T., Burke, J., Villholth, K., 2007. Groundwater: A global assessment of scale and significance. In: Molden, D. (Ed.), Watec tor tood, water tor lite, Earthscan, London, UK and IWMI, Colombo, Sri Lanka, pp. 395-423.

Shiferaw, B., Reddy. V.R., Wani, S.P., 2008. Watershed externalities, slitting cropping patterns and groundwater depletion in Indian semi-arid villages: The effect of alternative water pricing policies. Ecological Economics 67, 327-340.

Tsur, Y., Roe, T., Doukkali, R, Dinar, A., 2004. Pricing irrigation water: Principles and cases from developing countries. Resources for the Future, Washington, DC, USA

Tuinhof, A., Dumars, C., Foster, S., Kemper, H., Garduño, H., Nanni, M., 2003, Groundwater resource management: An introduction to its scope and practice. In World Bank Briefing note series No. 1. GW-Mate Core Group, World Bank, Washington, DC, USA.

Turner, $\mathrm{K}$, Georgiou, S. Clark, R, Brower, R. Burke, J., 2004. Economic valuation of water resources in agriculture. From the sectoral to a tunctional perspective of natural resource management. In: FAO Water Reports No. 27. FAO, Rome, Italy

Varela-Ortega, $C, 2007$. Policy-driven determinants of irrigation development and envitonmental sustainability: Acase study in Spain, In; Molle, F., Berkoff, J. (Eds.) Irrigation water pricing policy in context: Exploring the gap between theory and practice, Comprehensive Assessment of Water Management in Agriculture. IWMIfCABI, Wallingtord, UK and Cambridge, MA, USA, pp. 328-346.

Varela-Ortega, C., Blanco, I., 2008. Adaptive capacity and stakeholders' participation tacing water policies and agricultural policies. Paper presented at the XII Congress of the Europe an Association of Agricultural Economist (EAAE) on People, Food and Environments: Global Trends and European Strategies, Glent. Belgium, August 2008.

Varela-Ortega, C., Sumpsi, J.M., 1999. Assessment of cost-effectiveness of policy instruments for sustainable development in envicommentally semsitive incigation areas. Paper presented at the IX Congress of the European Association of Agricultural Economists (EAAE) on European Agriculture Facing the 21 st Century in a Global Context, Watsaw, Poland, August 1999.

Varela-Ortega, C.., Sumpsi,J.M., Garrido, A., Blanco, M., Iglesias, E., 1998. Water pricing policies, public decision making and tarmers' response: Implications tor water policy. Agricultural Economics 19, 193-202.

varela-Oitema, $C$, under revision. The contribution of stakeholder involvement tor balancing ecological and human systems in groundwater management. In: Von Korff, Y., Möllenkamp, S., Bots, P., Daniell, K., Biilsma, R. (Guest editors), Special Feature: Implementing Patticipatory Water Mandagement: Recent Advances in Theory, Practice and Evaluation. Ecology and Society (Ref No. ES-2009-3105).

Von Neuman, J. Morgensteri, 0., 1994. Theory of Games and Economic Behavior. Princeton University Press. Princeton, NJ.

WATECO, 2002. Economics and the environment. The implementation challenge of the Water Framework Directive. Common Implementation Strategy for the Water Framework Directive (2000/60/EC), Guidance Document No. 1, Water Economics working group for WFD economic studies, Office for official Publications of the European communities, Luxembourg.

Wheeler, S., Bjornlund, H., Shanahan, M., Zuo, A., 2008. Price elasticity of water allocations demand in the Goulburin-Murray Irtigation District. Australian Jourina of Agricultural and Resource Economics 52, 37-56.

Wichelns, D., 1999. Economic efficiency and irrigation water policy with an example from Esypt. Interinational Jou rnal of Water Resources Development 15, 543-560.

Zanou, B., Kontogianni, A., Skourtos, M., 2003. A classification approach of cost effective management measures for the improvement of watershed quality. Ocean \& Coastal Management 46, 957-983.

Zekri, S., Easter, W., 2005. Estimating the potential gains from water markets: A case study from Tunisia, Agricultural Water Management 72, 161-175.

Zorrilla, P., Carmona, G., De la Hera, A., Varela-Ortega, C., Martínez Santos, P., Bromky. J. Hentiksen, H.J., 2010. Bayesian netwotks as tools for patticipatory wate resources management: An application to the upper Guadiana Basin, Spain. In Von Korff, Y., Möllenkamp, S., Bots, P., Daniell, K., Biilsma, R. (Guest editors), Special teature: Implementing Patticipatory Water Management: Recent Advances in Theory, Practice and Evaluation. Ecology and Society 15(3), 12. 